\title{
A NEW CHOLESCINTIGRAPHIC AGENT: RUTHENIUM-97-DISIDA
}

\author{
I. Zanzil, S.C. Srivastava 2 , G.E. Meinken², W. Robeson', \\ L.F. Mausner ${ }^{2}$, R.G. Falrchild $\mathrm{d}^{2}$, and D. Margouleff 1 \\ lNorth Shore University Hospital, Cornell University Medical College
Manhasset, Long Island, New York 11030 \\ 2Medical Department, Brookhaven National Laboratory \\ Opton, Long Island, New York 11973
}

BNL- -38481

June, 1986

DE86 016169

\section{DISCLAIMER}

This report was prepared as an account of work sponsored by an agency of the United States Government. Neither the United States Government nor any agency thereor, nor any of their employees, makes any warranty, express or implied, or assumes any legal liability or responsibility for the accuracy, completeness, or usefulaess of any information, apparatus, product, or process disclosed, or represents that its use would not infringe privately owned rights. Reference herein to any specijsc commercial product, process, or service by trade nume, trademark, manufacturer, or utherwise does not necessarily constitute or imply its endorsement, recommendation, or favoring by the United States Government or any agency thereof. The views and opinions of authors expressed herein do no* necessarily state or reflect those of the United States Government or any agency thereor. 


\section{INTRODUCTION}

Although Tc-99m-IDA derivatives are the agents of cholce for most hepatoblliary lmaging, there are clinical conditions where the use of a longer-lived tracer is advantageous (1.e. differential diagaosis of neonatal hepatitis). Previous animal studies have suggested the usefulness of Ru-97-IDA de:ivatives as an alternative to I-13I Rose Bengal which has been used for this application (1). Ruthenium-97 has excellent imaging properties (Table 1) and is produced by proton spallation of rhodium foll at the BIIP (Brookheven Linac Isotope Producer) facility using the $\mathrm{Rh}-103(\mathrm{p}, 2 \mathrm{p} 5 \mathrm{n}) \mathrm{Ru}-97$ reaction (2). The labeling procedure is similar to the technique used to label DISIDA (2,6-di1sopropy lpheny l-carbamoylme thyliminodiacetic acid) with Tc-99m $(2,3)$. This is the first presentation of Ru-97-DISIDA Imaging in humans. We have explored the utilization of this radiopharmaceutical in patients with a variety of hepatobiliary clinical problems and also in conjunction with a solid test meal labeled with Tc-99m-Suifur Collold for the simultaneous observation and quantification of duodenogastric reflux and gastric emptying. This technique is an alternative to the simultaneous administration of TC-99m-DISIDA and a liquid meal labeled with In-111-DTPA or to the delayed administration of a solid meal labeled with Tc-99m-Sulfur Collold. A solld meal has the advantage of stimulating gallbladder emptying. 


\section{METHODS}

We utllized the previously reported method for labeling Ru-97-DISIDA (3). On occasion, the product, due to contamination of Ru-97 by small arounts of carrler, was not completely soluble in sailne. Use of $10 \%$ ethanol/saline eliminated this problem. Blodistribution studies were performed in normal BNL mice following injection of Ru-97-DISIDA $(0.2 \mathrm{ml})$ I.V. via the tail vein, with and without 107 ethanol. The animals were sacrificed 5, 30, and $120 \mathrm{~min}$ post-1njection and activity determined in tissue samples (Table 2).

For all patients, the commercially available DISIDA kit was utilized, with 10\% ethanol in the flal preparation. Patients fasted for at least 12 h prior to tracer administration. A LFOV camera fitted with a medium energy collimator was used with the photopeak window set at $216 \mathrm{keV} \pm 10 \%$. Sequential images of the superfor abdomen were obtalned during one hour following tracer injection. Delayed images were obtained as required. In some patients, gastric images were also obtained following the administration of Tc-99m-Sulfur Colloid in a standard meal (cooked egg whites, Lipomul, and water) (4) with the energy window set at $140 \mathrm{keV} \pm 10 \%$. There was no appreclable overlap between the Tc-99m and Ru-97 photopeaks. Enterogastric reflux and the gastric emptying were measured according to previously reported techniques $(4,5)$. Demographic data, diagroses, and administered doses for all patients are presented in Table 3. 
1. Blodistrfbution studies. Table 2 is a summary of typical data. Tissue distribution of Ru-DISIDA was very similar in the two groups of animals. Comparison with previous data $(1,3)$ reveals similarity to the distribution of corresponding TC-99m labeled agents. High hepatic uptake and negligible renal excretion were noted.

2. Patient studies. The hepatobiliary images obtained in patients vere of excelleni quality. Prompt blood clearance of the radlopharmaceutical was evident. Representative images are shown in Figures IA - 3. Image quality was excellent during the first hour and in delayed views. The Ru-97 scintiscans correlated well with other Imaging procedures and clinical findings (Table 2). For example, we were able to correctly rule out billary atresia in an infant in whom the gallbladder was not visualized. Surgical exploration revealed the presence of chronic and subacute cholecystitis and a patent common bile duct.

Simultaneous quantification of duodenogastric reflux (DGR) and gastric emptying (GE) were easily performed (Figures 2,3). As previously stated, the energy peaks of TC-99m and Ru-97 are sufficiently separated so that there was no spill-down of counts from the higher to the lower eaergy window (in the standard methodology, compensation for spill-down of In-111 counts into the Tc-99m window is essential before the quantification of DGR may be carried out) (4). 


\section{CONCLUSIONS}

These studies demonstrate the first application of Ru-97-DISIDA in human subjects. High quality lmages were obtalned. Scintigraphic findings in patients with hepatoblliary disorders were consistent with the blodistribution data obtalned in experimental arimals and with other imaging procedures and clinfcal. findings.

Adminlstration of Ru-97-DISIDA I.V. and of a solid test meal labeled with Tc-99m-Sulfur Colloid.allowed simultaneous detection and quantification of duodenogastric reflux and determination of the gastric emptying rate. This represents an advantage as compared to the currently used techniques which necessitate two separate studies if a solid meal is used, or would mandate a liquid meal for a simultaneous study.

The excellent nuclear decay characteristics of Ru-97 (t1/2 $69.6 \mathrm{~h}$, gamm 216 kev, $86 \%$, no betas) permit delayed study of the hepatoblliarj system ith considerably less radiation exposure than I-13I Rose Bengal and with a warked improvement in image quality. Further patient studies are in order to confirm the clinical utility of this agent. 


\section{REFERENCES}

(1) Schachner, E.R., G11, M.C., Atkins, H.L., Som, P., Srivastara, S.C., et al., J. Nuc1. Med. 22:352, 1981 .

(2) Srivastava, S.C., Richards, R., Som, R., et al., In: "Frontiers in Nuclear Medicine," Heidelberg, Springer-Verlag, 1980, pp 123-133.

(3) Srivastava, S.C., and Meinken, G. E., J. Labeled Compds. Radiopharm. 21: 1048, 1984.

(4) Tolin, R.D., Malmud, L.S., Stelzer, F., et al., Gastroenterology 77:1027, 1979.

(5) Horwitz, M., Collins, P.J., and Shearman, D.J.C., Arch. Int. Med. 148: 1467, 1985.

\section{Acknowledgments}

Research at Brookhaven supported under the 0.5 . Department of Energy Contract No. DE-ACO2-76CH00016. 
TABLE 1

Decay Data of $97_{\mathrm{Ru}}$

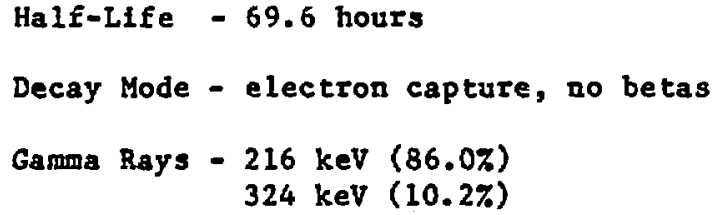

Production

Parame ters

\begin{tabular}{|c|c|}
\hline Nuclear Reaction & $-\quad{ }^{103} \mathrm{Rh}(p, 2 p 5 n)^{97} \mathrm{Ru}$ \\
\hline Target Material & - rhodlum foll, $0.25 \mathrm{~mm}$ thick \\
\hline Proton Energy & $-200 \mathrm{MeV}$ \\
\hline Production Rate & $-0.25 \mathrm{mCl} / \mu \mathrm{Ah}$ \\
\hline Total Yield & $\begin{array}{l}\text { - } 0.5-1 \text { C1 per run at } 80 \mu A \\
\text { with } 0.25 \mathrm{~mm} \text { thlek target }\end{array}$ \\
\hline Specific Activity & - carrler free \\
\hline Radiofmpurity & - none detectable \\
\hline
\end{tabular}


Tissue Distribution (Percent Dose Per Organ) of Ruthenium-103 Labeled Ace ta te and Dilsopropyl-IDA (DISIDA) in Mice ${ }^{1}$

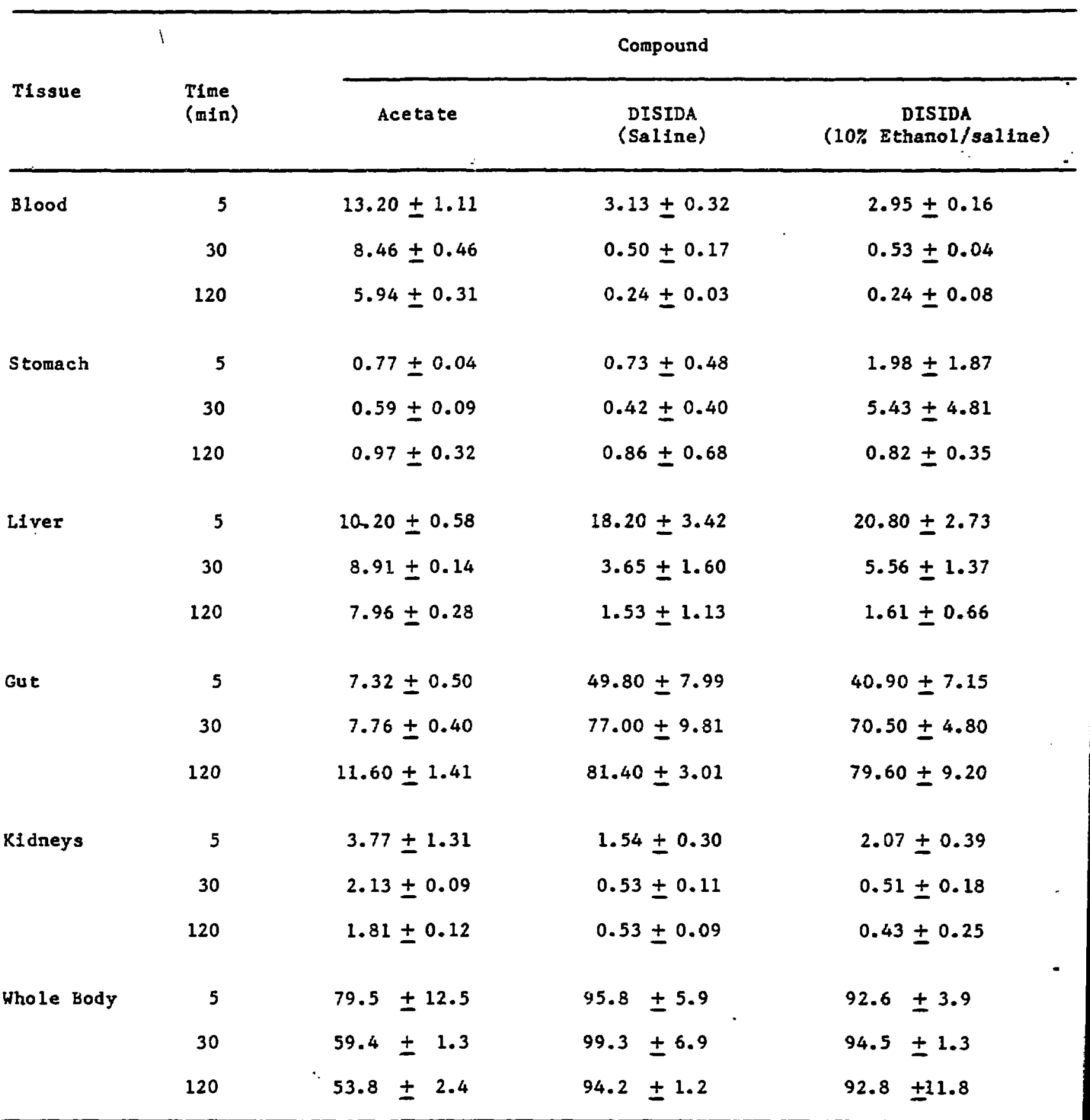

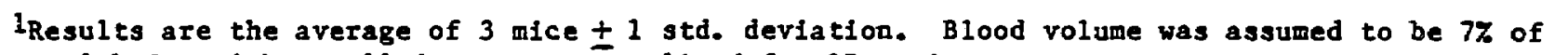
total body welght. All data were normalized for $25 \mathrm{~g}$ mice. 
Results of Ru-97-DISIDA Study in Patients

\begin{tabular}{|c|c|c|c|c|c|}
\hline Patient & Sex/Age & $\begin{array}{l}\text { Dose } \\
\text { (mC1) }\end{array}$ & $\begin{array}{l}\text { Scintigraphic } \\
\text { Diagnoses }\end{array}$ & & Confirmation \\
\hline 1 & F/84 & 0.70 & Acute cholecystitis & $(+)$ & Clinically \\
\hline 2 & $F / 34$ & 1.09 & Nozmal & $\stackrel{(+)}{(-)}$ & $\begin{array}{l}\text { Id. to repeat } 99 \mathrm{~m} \text { Te-DISIDA } \\
\text { Surg: Subacute cholecystitis }\end{array}$ \\
\hline 3 & $F / 14$ & 0.50 & $\begin{array}{l}\text { De layed } G E \text {. } \\
\text { DG reflux }(*)\end{array}$ & $(+)$ & Clinically \\
\hline 4 & $M / 5 I$ & 0.66 & Acute cholecystitis & $(+)$ & Surg: Subacute cholecystitis \\
\hline 5 & $M / 6 W$ & 0.09 & $\begin{array}{l}\text { Biliary atresia } R / \dot{O} \text {. } \\
\text { Non-visualization } G B\end{array}$ & $(+)$ & $\begin{array}{l}\text { Surg: Crisonic and subacute } \\
\text { cholecystitis }\end{array}$ \\
\hline 6 & F/23 & 0.80 & $\begin{array}{l}\text { Delayed } G E \text {. } \\
\text { No } D G \text { reflux }(*)\end{array}$ & $(+)$ & Clinically \\
\hline 7 & $M / 13$ & 0.96 & $\begin{array}{l}\text { Delayed GE. } \\
\text { No DG reflux (*) }\end{array}$ & $(?)$ & Suspected DGR by pH study \\
\hline 8 & $\mathrm{i} / 81$ & 1.32 & Chronic cholecystitis & $(+)$ & Clinically, US \\
\hline 9 & $M / 55$ & 1.40 & $\begin{array}{l}\text { Acute cholecystitis R/O. } \\
\text { Low grade obstruction } \\
\text { of CBD. }\end{array}$ & $(+)$ & $\begin{array}{l}\text { Surg: Chronic cholecystitis. } \\
\text { Cholelithiasis }\end{array}$ \\
\hline 10 & $M / 16$ & 0.75 & $\begin{array}{l}\text { Delayed GE. } \\
\text { No DG reflux (*) }\end{array}$ & $(3)$ & Suspected DGR by $\mathrm{pH}$ study \\
\hline 11 & $M / 16$ & 0.86 & $\begin{array}{l}\text { Normal } G E \text {. } \\
\text { No } D G \text { refiux (*) }\end{array}$ & $(+)$ & Clinically \\
\hline 12 & $F / 78^{\circ}$ & 0.83 & $\begin{array}{l}\text { High-grade obstruction } \\
\text { of CBD R/O. DG reflux? }\end{array}$ & $(+)$ & Borderline US, CT \\
\hline 13 & $E / 70$ & 1.00 & Acute cholecystitis & $(+)$ & $\begin{array}{l}\text { Surg: Chronic active } \\
\text { cholecystitis }\end{array}$ \\
\hline 14 & $M / 22$ & 0.79 & $\begin{array}{l}\text { Hepatic dysfunction. } \\
\text { Acute cholecystitis } R / 0 \text {. }\end{array}$ & $(+)$ & $\begin{array}{l}\text { Surg: Hodgkin's disease } \\
\text { of liver, cholestasis, } \\
\text { chronic cholecystitis }\end{array}$ \\
\hline
\end{tabular}

$D G=$ Duodenogastric reflux. $G E=$ Gastrlc emptying. $R / 0=$ Ruled out. $C B D=$ Common b1le.duct. US = Sonogram. $G B=$ Gallbladder. $(*)=$ Concomitant measurement of $D G$ and $G E$ using Tc-99m-Sulfur Colloid p.o. 
Figure 1. A. Sequential composite scintiphotos, 0-60 min p.1. Ru-97-DISIDA (1.1 mC1) ir patient No. 2. Prompt filling of the gallbladder and passage of tracer into the intestine are evident.

B. Scintiphotos, 10-60 inin p.1. Tc-99m-DISIDA (3.0 mCi) in same patient performed $17 \mathrm{~d}$ prior to previous test. Similar findings are noted In both examinations. 
Figure 2. A. Composite scintiphotos 0-40 min p.i. Ru-97-DISIDA in patient No. 3 . Images of the gallbladder, common bile duct, and duodenum. Suspicion of duodenogastric reflux at 30-40 min.

$B$ and $C$. Composite scintiphotos 0-60 min, patient No. 3, with (C) and without (B) superimposition of regions of interest corresponding to the liver and stomach. The gastric region was obtained following the administration of a solid meal labeled with Tc-99m-Sulfur Colloid, $100 \mu \mathrm{Ci}$. The billary reflux reaches the region of the stomach.

Figure 3. Sequential scintiphotos $0-90$ min post Tc-99m-Sulfur-Colloid in a solid test meal in patient No. 11. The first and third vertical columns from the left are Ru-97 images and the second and fourth column are Tc-99m views. Normal filling of GB, passage of tracer to the intestine, and gastric emptying are noted. Duodenogastic reflux is not present. 

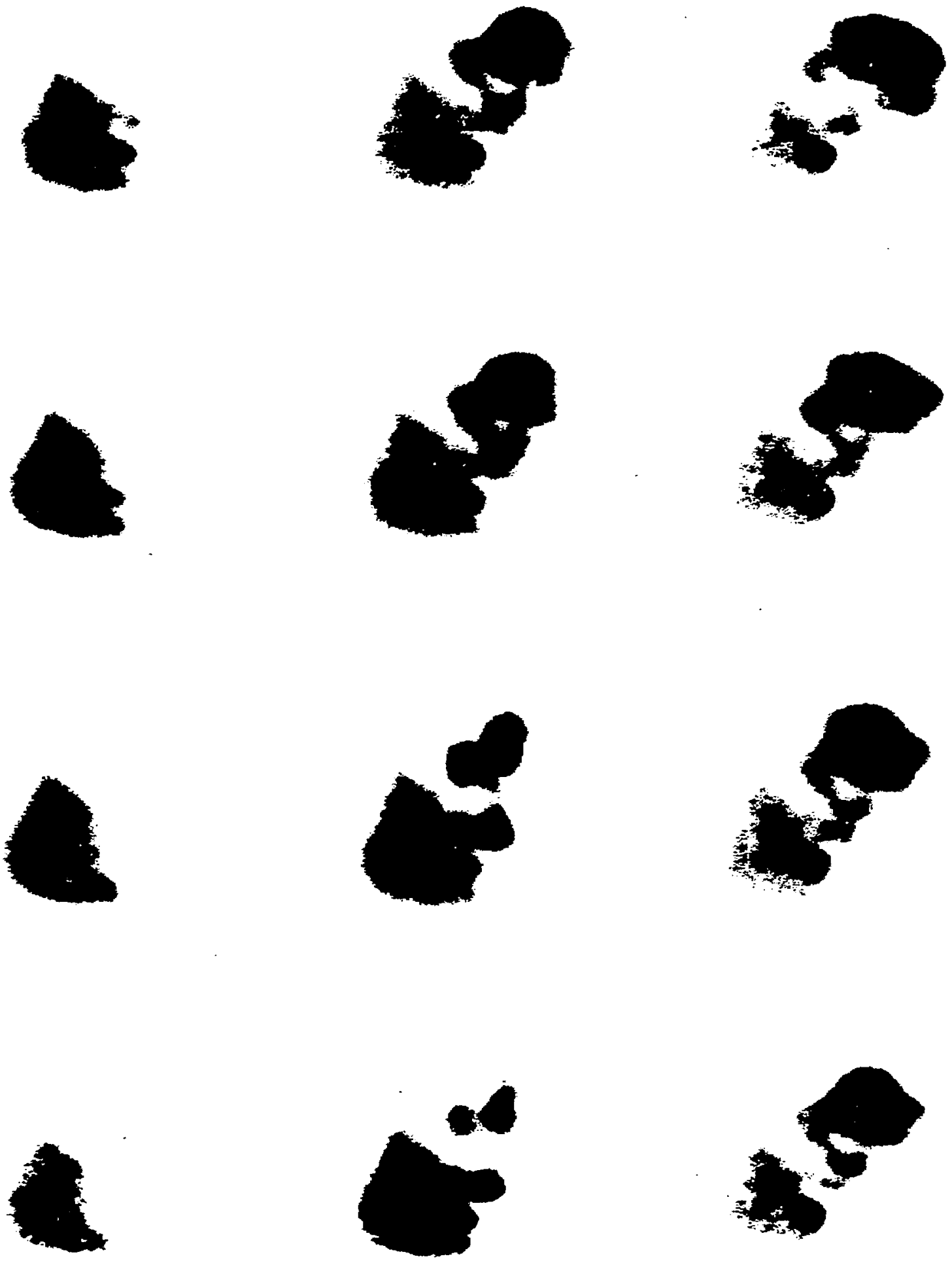

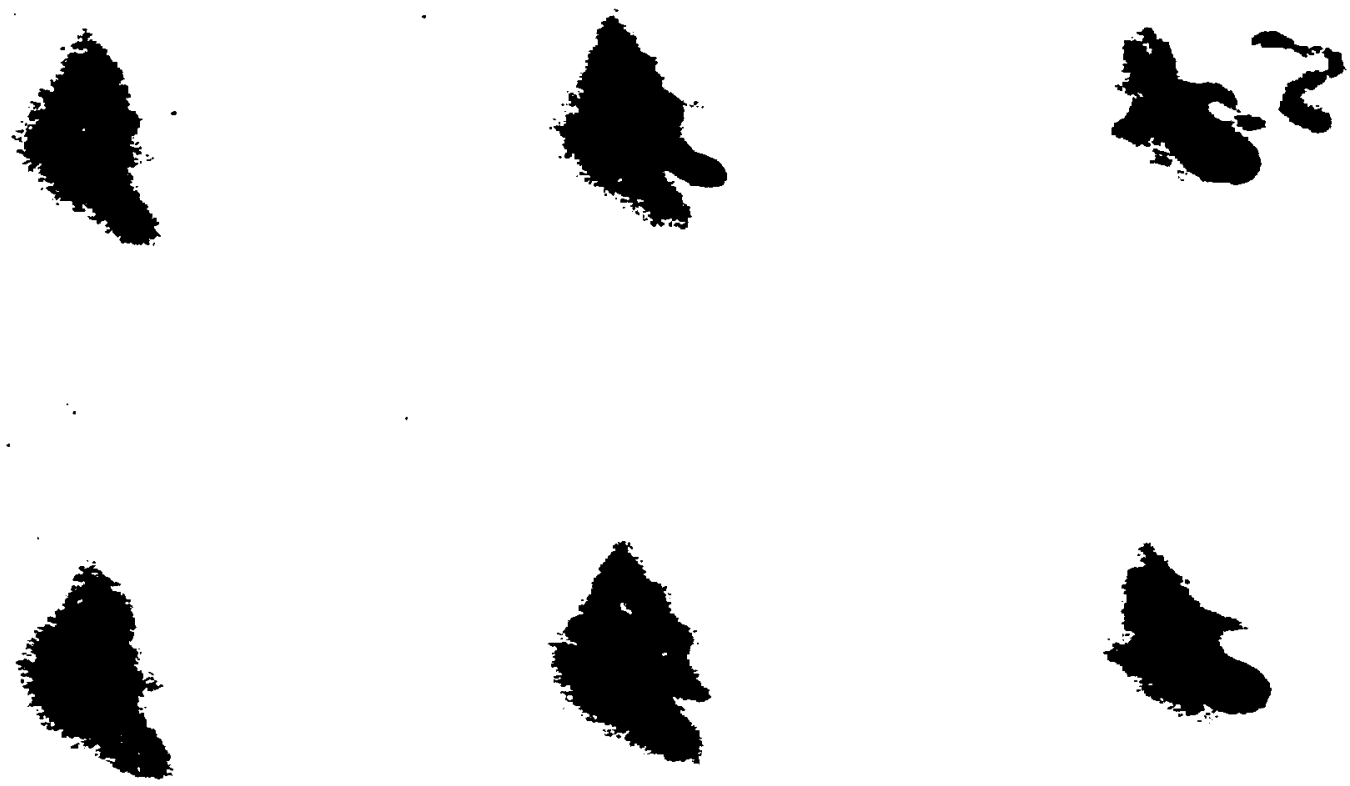

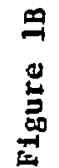
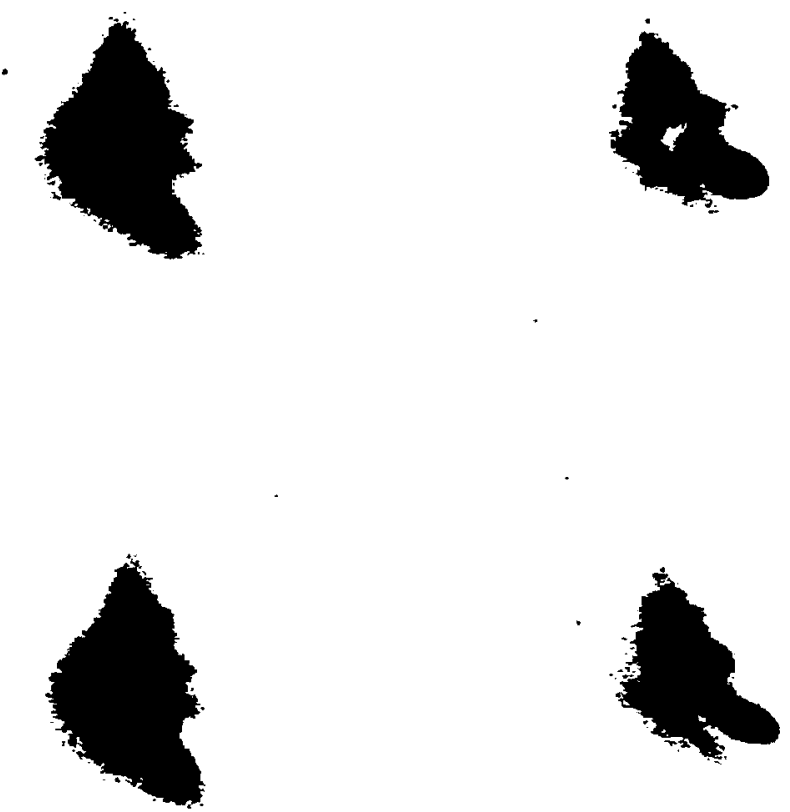
1)

Ig

E
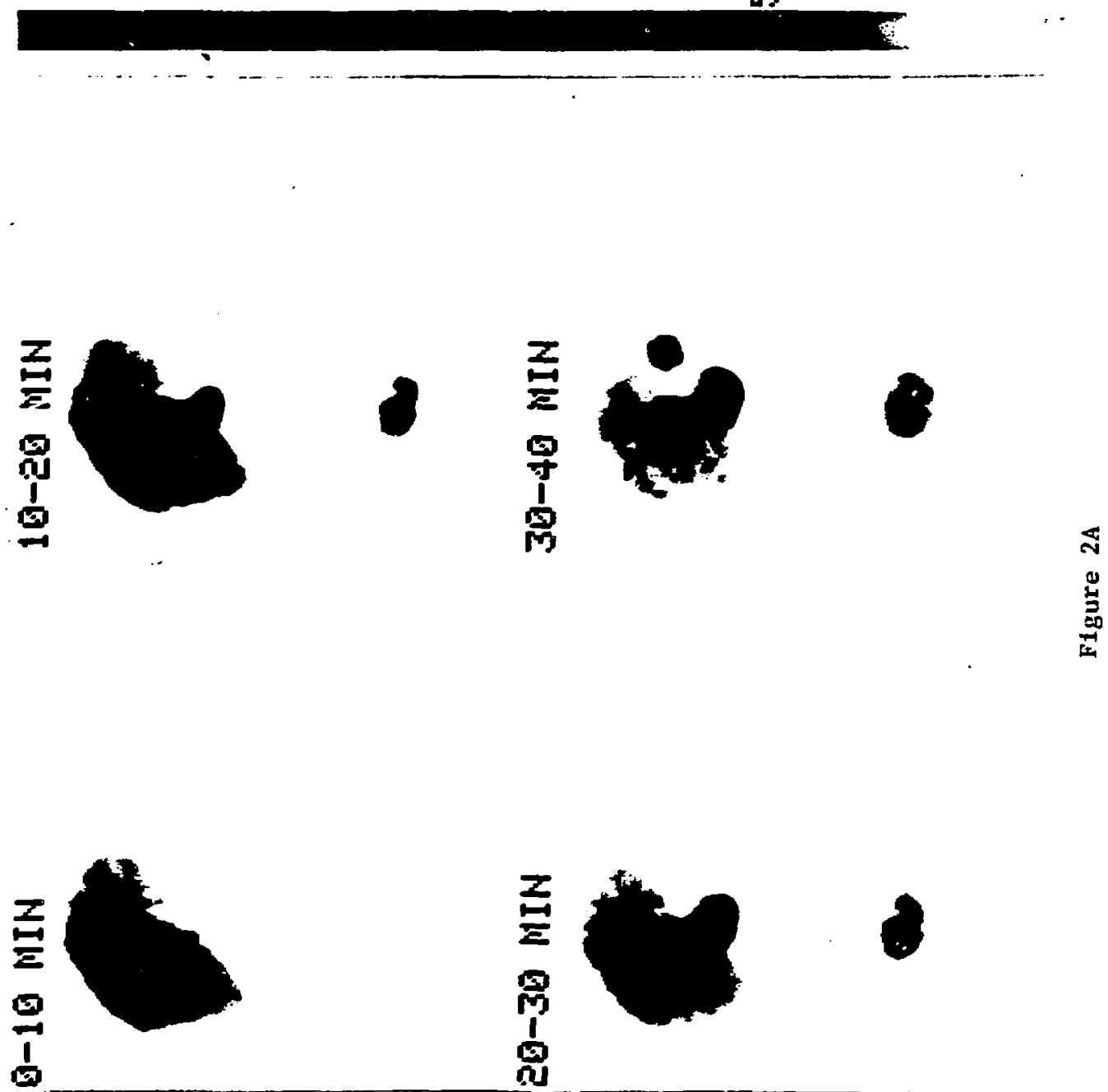


$$
\text { ? }
$$


r. III

r.

1

IT:

10

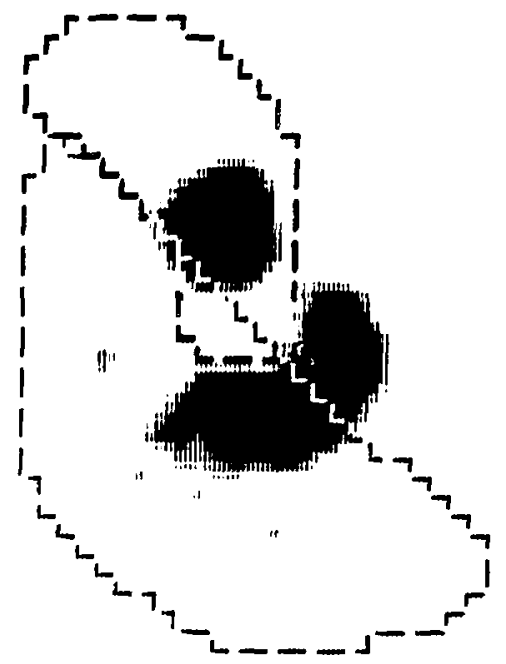

品 


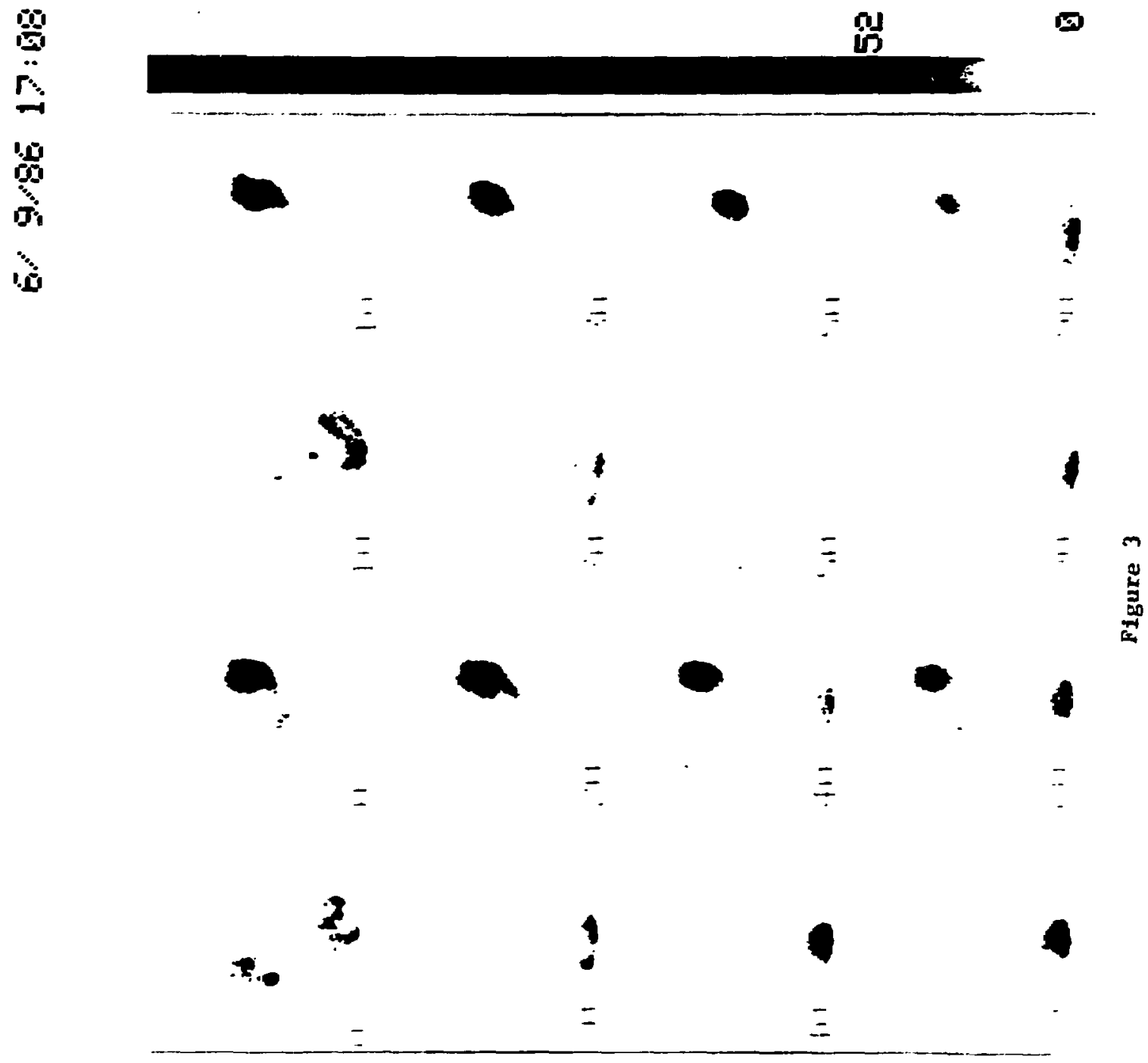

